\title{
Comparison the Error Rate of Autoregressive Distributed Lag (ARDL) and Vector Autoregressive (VAR) (Case study: Forecast of Export
} Quantities in DIY)

\section{Perbandingan Tingkat Kesalahan Metode Autoregresif Distribusi Lag (ARDL) dan Vektor Autoregresif (VAR) (Studi Kasus: Peramalan Jumlah Ekspor di DIY)}

\author{
Dewi Kusumaningrum ${ }^{1, a}$, Sugiyarto Surono ${ }^{1, b}$ \\ ${ }^{1}$ Faculty of Mathematics and Natural Sciences, Universitas Ahmad Dahlan, Jl. \\ Ringroad Selatan Tamanan, Banguntapan Bantul, Daerah Istimewa Yogyakarta, \\ Indonesia, 55191, 0823-3018-6929² alamat afiliasi \\ adewikusuma848@gmail.com, bugiyartophd@gmail.com
}

\begin{abstract}
Forecasting is estimating the size or number of something in the future. Regression model that enters current independent variable value, and lagged value is called distributed-lag model, if it enters one or more lagged value, it is called autoregressive. Koyck method is used for dynamic model which the lagged length is unknown, for the known lagged length it is used the Almon method. Vector Autoregressive (VAR) is a method that explains every variable in the model depend on the lag movement from the variable itself and all the others variable. This research aimed to explain the application of Autoregressive distributed-lag model and Vector Autoregressive (VAR) method for the forecasting for export amount in DIY. It takes export amount in DIY and inflation data, kurs, and Indonesia's foreign exchange reserve. Forecasting formation: defining Koyck and Almon distributed-lag dynamic model, then the best model is chosen and distribution-lag dynamic forecasting is performed. After that it is performed stationary test, co-integration test, optimal lag examination, granger causality test, parameter estimation, VAR model stability, and performs forecasting with VAR method. The forecasting result shows MAPE value from ARDL method obtained is $0.475812 \%$, while MAPE value from VAR method is $0.464473 \%$. Thus it can be concluded that Vector Autoregressive (VAR) method is more effective to be used in case study of export amount in DIY forecasting.
\end{abstract}

Keywords: Koyck, Almon, Lag, Autoregressive Distributed-Lag, Vector Autoregressive;

\begin{abstract}
Peramalan merupakan kegiatan memperkirakan apa yang terjadi pada masa yang akan datang. Model regresi yang memasukkan nilai variabel bebas saat ini, dan nilai masa lalu (lagged) disebut model terdistribusi-lag, apabila model tersebut memasukkan satu atau lebih nilai lagged disebut autoregresif. Metode Koyck digunakan untuk model dinamis yang panjang lagged tidak diketahui, untuk yang diketahui digunakan metode Almon. Vector Autoregressive (VAR) merupakan metode yang menjelaskan setiap variable dalam model tergantumg pada pergerakan masa lalu dari variabel itu sendiri dan juga seluruh variabel lainnya. Penelitian ini bertujuan untuk menjelaskan penerapan model Autoregressive terdistristribusi-lag dan metode Vektor Autoregresif (VAR) untuk
\end{abstract}


peramalan jumlah ekspor di DIY. Penelitian ini mengambil data jumlah ekspor di DIY dan data inflasi, kurs, serta cadangan devisa Indonesia.Pembentukan Peramalan: Menentukan model dinamis terdistribusi-lag Koyck dan Almon, lalu dipilih model terbaik dan dilakukan Peramalan dinamis terdistribusi-lag. Setelah itu melakukan uji stasioneritas, uji kointegrasi, pemeriksaan lag optimal, uji kausalitas granger, estimasi parameter, stabilitas model VAR, dan melakukan peramalan metode VAR. Hasil peramalan diperoleh nilai MAPE metode ARDL sebesar $0.475812 \%$, sedangkan untuk metode VAR diperoleh nilai MAPE sebesar $0.464473 \%$. Sehingga dapat disimpulkan bahwa metode Vektor Autoregresif (VAR) lebih efektif untuk digunakan dalam studi kasus peramalan jumlah ekspor di DIY.

Kata Kunci: Koyck, Almon, Lag, Autoregresif Distribusi Lag, Vektor Autoregresif.

\section{Introduction}

Forecasting is estimating the size or number of something in the future according to the lag that is analyzed naturally, especially using statistic method (Sudjana, 1986). Time series data are often used as input or output data for performing forecasting process. Some forecasting method that can be applied to perform forecasting according to the time series data include: naif approach method, moving average, exponential smoothing method, and trend projection method. The data used in this research is the historical data of export amount in DIY. Therefore, it will be performed a linear regression analysis that considers the time. The regression model whose dependent variable is influenced by the independent variable at the present time, and also influenced by the independent variable at the previous time is called the distributed lag model. If the dependent variable is influenced by the independent variable at the present time, and also influenced by the dependent variable itself at the previous time then the model is called autoregressive. Autoregressive model is also known as dynamic model if it describes the time line of the dependent variable in relation to its past value. Time difference or lag is the time required for the variable $\mathrm{X}$ in affecting the dependent variable $Y$. Koyck method is used for defining the estimation of distributed-lag dynamic model when the lag length is not known. Almon method is used for defining the estimation of distributedlag dynamic model when the lag length is known. Vector Autoregressive (VAR) is one of regression analysis method which explains that every variable exist in a model is depend on the previous movement from the variable itself and 
also the previous movement of the whole variable inside the system. In VAR analysis, the system model sought between time series variables in vector form to be used to determine the causality relationship (interrelation) of the variables (Gujarati, 2003). This research will compare the forecasting result between using Distributed-lag Autoregressive method and Vector Autoregressive (VAR) for the forecasting case study of export amount in DIY according to its error value. The variables used are inflation, exchange rate and foreign exchange reserve because it is suspected to have an effect towards the export amount in DIY.

\section{Materials and Methods}

\section{Ordinary Least Squares Method}

Least squares method (Ordinary Least Square/OLS) is a method to calculate $\mathrm{a}$ and $\mathrm{b}$ in the regression equation as $\alpha$ and $\beta$ approximation, such that the sum of error squares has the smallest value. The estimation of $\beta_{0}, \beta_{1}$ is obtained the following formula (1)

$$
\widehat{\beta}=\left(X^{T} X\right)^{-1} X^{T} y
$$

There are two testing parameter that is used for knowing whether the independent variables inside the regression model significantly influence the dependent variable, regression significance test (F test) and individual regression coefficient test (t test). The important things in classic assumption test are normality test, heteroscedasticity test, autocorrelation test, multicollinearity test, and error dependency test (Gujarati, 2003).

\section{Stationarity Test of Time Series Data}

In time series analysis, stationarity assumption of the data is an important character. In stationary model, the future statistics characteristics can be forecasted according to the historical data that has happened in the past. After the stationary test at the data then cointegration test, optimal lag test, Granger causality test, parameter estimation, and VAR model stability test are performed (Rosadi, 2012).

\section{Optimal Lag Examination}

Optimal Lag Examination is used to determine optimal lag length which be used to determine the parameter estimation of VAR model. This can be caused by causal relationship and VAR model which are sensitive toward the lag length, so it is necessary to determine the proper optimal lag length (Widarjono, 2007). To determine the optimal lag length in VAR model, it can be used information criteria as Akaike Information Criteria (AIC). The 
calculation of AIC is written as follows (2) :

$$
\left.\mathrm{AIC}=\ln \left(\frac{\mathrm{RSS}}{\mathrm{n}}\right)+\frac{2 \mathrm{k}}{\mathrm{n}}\right)
$$

with

$$
\begin{aligned}
\text { RSS } & =\text { residual sum of squares } \\
\mathrm{k} & =\text { sum of estimated } \\
\mathrm{n} \quad & \begin{array}{l}
\text { parameters } \\
=\text { number of observations }
\end{array}
\end{aligned}
$$

The optimal lag is on the smallest value obtained in calculation (Widarjono, 2007).

\section{Autoregressive Distributed Lag Model}

Dynamic model is a model that describes the movement of the dependent variables which is influenced by the value from the past. The required time for independent variable $\mathrm{X}$ in influencing dependent variable $\mathrm{Y}$ is called time difference or lag or time-lag. There are 2 kinds of linear regression model that pays attention to the time influence, there are:

\section{Distributed Lag Model}

When a dependent variable is influenced by the independent variable in the current time, and if it is also influenced by the independent value in the previous time, then it is called distributed lag model. There are 2 kinds of distributed lag:

\section{a. Infinite Lag Model}

Equation (3)

$$
\begin{array}{ll}
\mathrm{Y}_{t} & =\alpha+\beta_{0} \mathrm{X}_{t}+\beta_{1} \mathrm{X}_{t-1}+\beta_{2} \\
& \mathrm{X}_{t-2}+\ldots+\varepsilon_{t}
\end{array}
$$

\section{b. Finite Lag Model}

Equation (4)

$$
\begin{array}{ll}
\mathrm{Y}_{t} & =\alpha+\beta_{0} \mathrm{X}_{t}+\beta_{1} \mathrm{X}_{t-1}+\beta_{2} \mathrm{X}_{t-2}+ \\
& \ldots+\beta_{k} \mathrm{X}_{t-k}+\varepsilon_{t}
\end{array}
$$

\section{Autoregressive Model}

If the dependent variable is affected by the independent variable in the current time, and also affected by dependent variable itself in the previous time, so it called autoregressive model.

$$
Y_{t}=\alpha+\beta_{1} X_{t}+\beta_{2} Y_{t-1}+\varepsilon_{t}
$$

This is the example of autoregressive model, which is also known as dynamic model, because it is figure out the timeline from the dependent variable with the value from the previous time (Gujarati, 2003).

\section{Koyck Method}

Koyck Method usually used to determine the estimated dynamic distributed lag model, which the length of the lag is unknown (3)

$$
\begin{aligned}
& Y_{t}=\alpha+\beta_{0} X_{t}+\beta_{1} X_{t-1}+\beta_{2} X_{t-2}+\ldots+ \\
& \varepsilon_{t}
\end{aligned}
$$

Koyck assumed that $\beta$ coefficient was decreasing geometrically as follow:

$$
\beta_{k}=\beta_{0} \lambda^{k}, \mathrm{k}=0,1, \ldots \text { dan } 0<\lambda<1
$$


Where $\lambda$ is the decreasing of distributed-Lag, Koyck Model was written as follow:

$\mathrm{Y}_{t}=\alpha(1-\lambda)+\beta_{0} \mathrm{X}_{t}+\lambda \mathrm{Y}_{t-1}+\mathrm{V}_{t}$

Which Vt $=\varepsilon_{t}-\lambda \varepsilon_{t-1}$.

Pay attention to this Koyck scheme features:

1) By assuming the value of $\lambda$ is not important, Koyck tooe a side of $\beta$ 's by the change the sign;

2) By assuming the value of $\lambda<1$, He gave small integrity to $\beta$ 's which is far from now;

3) He define that the value of $\beta$ 's is a sum of limited long term (Gujarati, 2003).

\section{Almon Method}

Almon method used to determine the estimated of dynamic distributedlag, which the length of the lag is known. The model that used in the almon method is finite lag (3) method as follow:

$$
\begin{aligned}
Y_{t} & =\alpha+\beta_{0} X_{t}+\beta_{1} X_{t-1}+\beta_{2} X_{t-2}+ \\
& \ldots+\beta_{k} X_{t-k}+\varepsilon_{t}
\end{aligned}
$$

or

$$
\mathrm{Y}_{t}=\alpha+\sum_{\mathrm{i}=0}^{\mathrm{k}} \beta_{\mathrm{i}} \mathrm{X}_{t-i}+\varepsilon_{t}
$$

Based on the mathematics theory which is well known as Weir-Strass's Theorem, Almon assumed that $\beta$ i can be approached by a certain polynomial in the $\mathrm{i}$ which has degree, With $\mathrm{i}$ is the length of the lagged. That Polynomial degree could be $0,1,2, \ldots$ etc. For example, if $\beta$ i was following polynomial of second degree of the model, so it can be written as:

$$
\beta_{\mathrm{i}}=\alpha_{0}+\alpha_{1} \mathrm{i}+\alpha_{2} \mathrm{i}^{2}
$$

By distributing equation (2) to (1), obtained

$$
\begin{aligned}
\mathrm{Y}_{t} & =\alpha+\sum_{\mathrm{i}=0}^{\mathrm{k}}\left(\alpha_{0}+\alpha_{1} \mathrm{i}+\alpha_{2} \mathrm{i}^{2}\right) \\
& \mathrm{X}_{t-i}+\mathrm{u}_{t} \\
& =\alpha+\alpha_{0} \sum_{\mathrm{i}=0}^{\mathrm{k}} \mathrm{X}_{\mathrm{t}-\mathrm{i}}+ \\
& \alpha_{1} \sum_{\mathrm{i}=0}^{\mathrm{k}} \mathrm{i} \mathrm{X}_{\mathrm{t}-\mathrm{i}}+\sum_{\mathrm{i}=0}^{\mathrm{k}} \mathrm{i}^{2} \mathrm{X}_{\mathrm{t}-\mathrm{i}}+ \\
& \mathrm{u}_{t}
\end{aligned}
$$

If defined:

$$
\begin{aligned}
& \mathrm{Z}_{0 t}=\sum_{\mathrm{i}=0}^{\mathrm{k}} \mathrm{X}_{\mathrm{t}-\mathrm{i}} \\
& \mathrm{Z}_{1 t}=\sum_{\mathrm{i}=0}^{\mathrm{k}} \mathrm{i} \mathrm{X}_{\mathrm{t}-\mathrm{i}} \\
& \mathrm{Z}_{2 t}=\sum_{\mathrm{i}=0}^{\mathrm{k}} \mathrm{i}^{2} \mathrm{X}_{\mathrm{t}-\mathrm{i}}
\end{aligned}
$$

So it will be:

$$
\begin{aligned}
& \mathrm{Y}_{t}=\alpha+\alpha_{0} \quad \mathrm{Z}_{0 t}+\alpha_{1} \mathrm{Z}_{1 t} \\
& +\alpha_{2} \mathrm{Z}_{2 t}+\varepsilon_{t}
\end{aligned}
$$

Equation (11) can be predicted by OLS Procedure. The probability of $\widehat{\alpha}$ and $\widehat{\alpha}_{1}$ that will be possess the desired properties if only the error $\mathrm{u}_{t}$ full filled the classic assumption. After all $\widehat{\alpha}_{1}$ predicted from equation (10), coefficient $\beta$ can be calculated using equation (9) as follow:

$$
\widehat{\beta}_{\mathrm{k}}=\widehat{\alpha}_{0}+\mathrm{k} \widehat{\alpha}_{1}+\mathrm{k}^{2} \widehat{\alpha}_{2}
$$

So the estimation of distributed lag model is:

$$
\begin{aligned}
\hat{\hat{Y}}_{t} & =\widehat{\alpha}+\widehat{\beta}_{0} X_{t} \\
& +\widehat{\beta}_{1} X_{t-1}+\widehat{\beta}_{2} X_{t-2}+\ldots \\
& +\widehat{\beta}_{k} X_{t-k}
\end{aligned}
$$




\section{Vector Autoregressive Method (VAR)}

Vector Autoregressive (VAR) is a system of dynamic equation that used to test the connection between the variables by using minimum assumption based on the structure. Vector Autoregressive (VAR) was first up come by Sims (1980). VAR explains that every variable is depend on the movement from the previous time of its variable, and also depends on the previous time movement of all variables that exist in the system. In the VAR analysis, determined the equation of a model system from the pull out times variables in the form of vector, this will be used to find out the interrelationship from the variables (Gujarati, 2003). The scale of pull out times $y_{t}$ can be written in the autoregressive as follow:

$\mathrm{Y}_{t}=\alpha+\beta_{1} \mathrm{Y}_{t-1}+\beta_{2} \mathrm{Y}_{t-2}+\ldots+\beta_{p} \mathrm{Y}_{t-p}$ $+\varepsilon_{t}$

Then from the equation above it will be obtained these following vectors:

$$
\begin{gathered}
\mathrm{y}_{t}=\left(\mathrm{y}_{1 t} \mathrm{y}_{2 t} \mathrm{y}_{3 t} \ldots \mathrm{y}_{n t}\right) \\
\mathrm{y}_{1 t-1}=\left(\mathrm{y}_{11 t-1} \mathrm{y}_{12 t-1} \mathrm{y}_{13 t-1} \cdots \mathrm{y}_{1 n t-1}\right) \\
\mathrm{y}_{1 t-2}=\left(\mathrm{y}_{11 t-2} \mathrm{y}_{12 t-2} \mathrm{y}_{13 t-2} \cdots \mathrm{y}_{1 n t-2}\right) \\
\vdots \\
\mathrm{y}_{1 t-p}=\left(\mathrm{y}_{11 t-p} \mathrm{y}_{12 t-p} \mathrm{y}_{13 t-p} \cdots \mathrm{y}_{1 n t-p}\right)
\end{gathered}
$$

And vector $\left(\alpha_{1} \alpha_{2} \alpha_{3} \ldots \alpha_{n}\right)$ as $\alpha$.

$\alpha_{1} \alpha_{2} \alpha_{3} \ldots \alpha_{n}$ estimated by formula:

$\hat{a}=\frac{\left(\Sigma y_{t}\right)\left(\Sigma y_{t-1}^{2}\right)-\left(\Sigma y_{t-1}\right)\left(\Sigma y_{t-1} y_{t}\right)}{n \Sigma y_{t-1}^{2}-\left(\Sigma y_{t-1}\right)^{2}}$ $\beta_{11}, \beta_{12}, \beta_{13}, \ldots, \beta_{n n}$ estimated by formula:

$$
\widehat{\beta}=\frac{\mathrm{n}\left(\Sigma y_{t-1} y_{t}\right)-\left(\sum y_{t-1}\right)\left(\sum \mathrm{y}_{t}\right)}{n \Sigma y_{t-1}^{2}-\left(\sum y_{t-1}\right)^{2}}
$$

So, obtained the matrix

$$
\beta_{n}=\left[\begin{array}{cccr}
\beta_{11(-p)} & \beta_{12(-p)} & \ldots & \beta_{1 n(-p)} \\
\beta_{21(-p)} & \beta_{22(-p)} & \ldots & \beta_{2 n(-p)} \\
\cdots & \ldots & \ldots & \ldots \\
\beta_{n 1(-p)} & \beta_{n 2(-p)} & \ldots & \beta_{n n(-p)}
\end{array}\right]
$$

Vector $\left(\begin{array}{lllll}\varepsilon_{1 t} & \varepsilon_{2 t} & \varepsilon_{3 t} & \ldots & \varepsilon_{n t}\end{array}\right)$ as $\varepsilon_{t}$

\section{Discussion}

\begin{tabular}{|c|c|c|c|c|}
\hline Variable & Coefficient & Std. Error & $\mathrm{t}$-Statistic & Prob. \\
\hline $\mathrm{C}$ & 2.6336 & 0.3907 & 6.7407 & 0.0000 \\
\hline KURS & $1.1 \mathrm{E}-05$ & $2.9 \mathrm{E}-06$ & 3.8128 & 0.0004 \\
\hline LOGEKSPOR(-1) & -0.0173 & 0.1504 & -0.1149 & 0.9091 \\
\hline R-squared & 0.3162 & \multicolumn{2}{|c|}{ Mean dependent var } & 2.7204 \\
\hline Adjusted R-squared & 0.2851 & \multicolumn{2}{|c|}{ S.D. dependent var } & 0.0245 \\
\hline S.E. of regression & 0.0207 & \multicolumn{2}{|c|}{ Akaike info criterion } & -4.8569 \\
\hline Sum squared resid & 0.0188 & \multicolumn{2}{|c|}{ Schwarz criterion } & -4.7388 \\
\hline Log likelihood & 117.1365 & \multicolumn{2}{|c|}{ Hannan-Quinn criter. } & -4.8124 \\
\hline F-statistic & 10.1710 & \multicolumn{2}{|c|}{ Durbin-Watson stat } & 1.9867 \\
\hline Prob(F-statistic) & 0.0002 & & & \\
\hline
\end{tabular}

\section{Koyck Model Formation}

In order to makes analysis become easier the researcher using software Eviews 10.

Table 1. Estimated of Koyck model 
Based on the table 1 Obtained the analysis result:

$\mathrm{Y}_{t}=-2.633554+0.0000109 \mathrm{X}_{t^{-}}$ $0.017276 \mathrm{Y}_{t-1}$

So the predicted lagged model is :

$\widehat{\mathrm{Y}}=2.58882938+0.0000109 \mathrm{X}_{\mathrm{t}^{-}}$ $0.0000001883084 \mathrm{X}_{\mathrm{t}-1}$ $0.000000003253215918 \mathrm{X}_{\mathrm{t}-2}$ $0.0000000000562026 \mathrm{X}_{\mathrm{t}-3}$ $0.000000000000970955 \mathrm{X}_{\mathrm{t}-4}$

On the estimated equation it can be seen that the effect of lag $Y$ does not decrease geometrically. Estimated dynamic equation does not fulfiled the criteria of Koyck method which assumed that $\beta$ coefficient decrease geometrically so the Koyck method cannot be used.

\section{Almon Method Formation}

Based on the table result, it was obtained that the estimated equation of Almon regression:

$$
\begin{aligned}
& \hat{Y}=2.596293+0.0000163 \mathrm{Z}_{0 t}- \\
& 0.0000479 \mathrm{Z}_{1 t}+0.0000166 \mathrm{Z}_{2 t}
\end{aligned}
$$

Table 2. Estimated of Almon model

\begin{tabular}{|l|c|c|c|c|}
\hline \multicolumn{1}{|c|}{ Variable } & Coefficient & Std. Error & t-Statistic & Prob. \\
\hline C & 2.5963 & 0.0319 & 81.3465 & 0.0000 \\
\hline Z0T & $1.6 \mathrm{E}-05$ & $9.5 \mathrm{E}-06$ & 1.7142 & 0.0940 \\
\hline Z1T & $-4.8 \mathrm{E}-05$ & $2.3 \mathrm{E}-05$ & -2.1148 & 0.0406 \\
\hline Z2T & $1.7 \mathrm{E}-05$ & $7.4 \mathrm{E}-06$ & 2.2382 & 0.0307 \\
\hline \multicolumn{5}{|l|}{} \\
\hline R-squared & 0.3598 & Mean dependent var & 2.7217 \\
\hline Adjusted R-squared & 0.3130 & S.D. dependent var & 0.0240 \\
\hline S.E. of regression & 0.0199 & Akaike info criterion & -4.9086 \\
\hline Sum squared resid & 0.0163 & Schwarz criterion & -4.7480 \\
\hline Log likelihood & 114.4428 & Hannan-Quinn criter. & -4.8487 \\
\hline F-statistic & 7.6824 & Durbin-Watson stat & 1.9513 \\
\hline Prob(F-statistic) & 0.0004 & \multicolumn{2}{l}{} \\
\hline
\end{tabular}

Based on the table of $F$ test it is concluded that $\mathrm{Z}_{0 t}, \mathrm{Z}_{1 t}, \mathrm{Z}_{2 t}$ significantly affected to the dependent variable of export amount. Based on the $t$ test it is concluded that the value of $\mathrm{Z}_{0 t}$, is not significant so variable $\mathrm{Z}_{0 t}$ does not used. Then the estimated equation of almon regression become:
$\widehat{Y}=2.596293-0.0000479 \mathrm{Z}_{1 t}+$ $0.0000166 Z_{2 t}$

So it will obtain the estimated lagged model:

$\widehat{Y}=2.596293-0.0000313 \mathrm{X}_{t-1^{-}}$

$0.000046 \mathrm{X}_{t-2}-0.0000422 \mathrm{X}_{t-3}$

Classic assumption test (nonautocorelation, homoskedastisitas) was fulfilled, meanwhile multicolinearity 
test was not fulfilled because determined from the degree of polynomial. Obtained the MAPE value of data training on the Almon method is about $0.513211 \%$, MAPE value of data testing is $0.335563 \%$, and MAPE value of 2013 to 2017 is $0.475812 \%$.

\section{VAR Model Formation}

Based on the optimal lag test it is obtained the value of optimal lag on the lag 1.

Table 3. Optimal Lag Test

\begin{tabular}{|c|c|c|c|c|c|c|}
\hline Lag & LogL & LR & FPE & AIC & SC & HQ \\
\hline 0 & -560.98 & NA & 3037916 & 26.28 & 26.44 & 26.34 \\
\hline 1 & -427.10 & 236.62 & 12685.57 & 20.80 & 21.61 & $21.10^{*}$ \\
\hline 2 & -419.72 & 11.67 & 19339.73 & 21.20 & 22.67 & 21.74 \\
\hline 3 & -409.29 & 14.56 & 26414.27 & 21.55 & 23.59 & 22.24 \\
\hline 4 & -397.53 & 14.22 & 35706.06 & 21.65 & 24.44 & 22.68 \\
\hline 5 & -376.97 & 21.04 & 34653.19 & 21.44 & 24.88 & 22.71 \\
\hline
\end{tabular}

Table 4. VAR parameters estimation

\begin{tabular}{|c|c|c|c|c|}
\hline & LOG EKSPOR & INFLASI & KURS & $\mathrm{CD}$ \\
\hline LOG EKSPOR (-1) & $\begin{array}{r}-0.219508 \\
(0.15818) \\
{[-1.38773]}\end{array}$ & $\begin{array}{r}-0.073686 \\
(0.06354) \\
{[-1.15973]}\end{array}$ & $\begin{array}{c}1807.829 \\
(2106.38) \\
{[0.85826]}\end{array}$ & $\begin{array}{r}18597.36 \\
(22622.7) \\
{[0.82207]}\end{array}$ \\
\hline INFLASI (-1) & $\begin{array}{r}-0.220970 \\
(0.18971) \\
{[-1.16475]}\end{array}$ & $\begin{array}{c}0.870072 \\
(0.07621) \\
{[11.4175]}\end{array}$ & $\begin{array}{c}4138.902 \\
(2526.35) \\
{[1.63830]}\end{array}$ & $\begin{array}{r}-5448.456 \\
(27133.2) \\
{[-0.20080]}\end{array}$ \\
\hline KURS (-1) & $\begin{array}{r}9.35 \mathrm{E}-06 \\
(2.6 \mathrm{E}-06) \\
{[3.61209]}\end{array}$ & $\begin{array}{r}-1.73 \mathrm{E}-06 \\
(1.0 \mathrm{E}-06) \\
{[-1.66375]}\end{array}$ & $\begin{array}{c}0.942374 \\
(0.03447) \\
{[27.3423]}\end{array}$ & $\begin{array}{r}0.391501 \\
(0.37017) \\
{[1.05764]}\end{array}$ \\
\hline $\mathrm{CD}(-1)$ & $\begin{array}{c}1.36 \mathrm{E}-06 \\
(6.3 \mathrm{E}-07) \\
{[2.14460]}\end{array}$ & $\begin{array}{c}1.48 \mathrm{E}-07 \\
(2.5 \mathrm{E}-07) \\
{[0.57978]}\end{array}$ & $\begin{array}{c}0.002546 \\
(0.00845) \\
{[0.30145]}\end{array}$ & $\begin{array}{r}0.840177 \\
(0.09072) \\
{[9.26109]}\end{array}$ \\
\hline $\mathrm{C}$ & $\begin{array}{r}3.071490 \\
(0.39607) \\
{[7.75488]}\end{array}$ & $\begin{array}{c}0.213186 \\
(0.15910) \\
{[1.33999]}\end{array}$ & $\begin{array}{r}-4646.665 \\
(5274.31) \\
{[-0.88100]}\end{array}$ & $\begin{array}{r}-37907.98 \\
(56646.5) \\
{[-0.66920]}\end{array}$ \\
\hline R-squared & 0.427907 & 0.840026 & 0.963340 & 0.811450 \\
\hline Adj. R-squared & 0.373422 & 0.824791 & 0.959848 & 0.793493 \\
\hline Sum sq. resids & 0.015754 & 0.002542 & 2793577. & $3.22 \mathrm{E}+08$ \\
\hline S.E. equation & 0.019367 & 0.007779 & 257.9026 & 2769.896 \\
\hline F-statistic & 7.853670 & 55.13574 & 275.9146 & 45.18822 \\
\hline Log likelihood & 121.3296 & 164.1979 & -325.0182 & -436.5954 \\
\hline Akaike AIC & -4.950195 & -6.774378 & 14.04333 & 18.79130 \\
\hline
\end{tabular}

Comparison the Error Rate of Autoregressive Distributed Lag (ARDL) and

Vector Autoregressive (VAR) ...... 
Table 4. VAR parameters estimation (Continued)

\begin{tabular}{lcccc}
\hline \hline & LOG EKSPOR & INFLASI & KURS & CD \\
\hline \hline Schwarz SC & -4.753371 & -6.577554 & 14.24015 & 18.98812 \\
Mean dependent & 2.720352 & 0.058513 & 12311.04 & 106397.0 \\
S.D. dependent & 0.024467 & 0.018585 & 1287.077 & 6095.317 \\
\hline \hline Determinant resid covariance (dof adj.) & 7103.760 & & \\
Determinant resid covariance & 4529.956 & & \\
Log likelihood & -464.5944 & & \\
Akaike information criterion & & 20.62104 & & \\
Schwarz criterion & 21.40834 & & \\
Number of coefficients & & 20 &
\end{tabular}

Rely on the table of estimated result of VAR method it is obtained VAR(1) model as follow:

ekspor $_{t}=$

3.071490-0.219508 ekspor $_{t-1^{-}}$ $0.220970 \quad$ inflasi $_{t-1} \quad+$ 0.00000935 kurs $_{t-1} \quad+$ $0.00000136 \mathrm{CD}_{t-1}$ inflasi $_{t}=$

$0.213186-0.073686$ ekspor $_{t-1}+$ 0.870072 inflasi $_{t-1}-0.00000173$ kurs $_{t-1}$ $+0.000000148 \mathrm{CD}_{t-1}$

$\operatorname{kurs}_{t}=$

$-4646.665+1807.829$ ekspor $_{t-1}+$

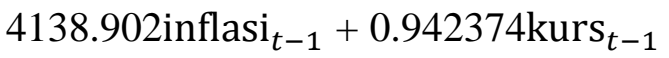
$+0.002546 \mathrm{CD}_{t-1}$

$\mathrm{CD}_{t}=$

$-37907.98+18597.36$ ekspor $_{t-1^{-}}$ 5448.456 inflasi $_{t-1}+0.391501$ kurs $_{t-1}$ $+0.840177 \mathrm{CD}_{t-1}$

Based on the result of VAR stability test from the table it is obtained all of modulus value is less than one, so it can be concluded that VAR system is stable. The MAPE value of data training on the VAR model is $0.4734 \%$, MAPE value of data testing is $0.4338 \%$ and MAPE value of 2013 to 2017 is $0.464473 \%$.

\section{Determination of the best method}

The determination of the best method was done by comparing the MAPE value from the Auto regressive Distributed-Lag (ARDL) and Vector Autoregressive (VAR) method. The MAPE value of data training on the Almon method is about $0.513211 \%$, MAPE value of data testing is $0.335563 \%$, and MAPE value of 2013 to 2017 is $0.475812 \%$. Meanwhile for the VAR method it is obtained the MAPE value of data training on the VAR model is $0.4734 \%$, MAPE value of data testing is $0.4338 \%$ and MAPE value of 2013 to 2017 is $0.464473 \%$. So it can be concluded that Vector Autoregressive (VAR) method was 
more effective to be used in case study comparison of MAPE value can be seen of export amount in DIY forecasting. on the table 5:

The forecasted result of 2018 and the

Table 5. Forecasted result of 2018

\begin{tabular}{|c|c|c|c|c|c|}
\hline Month & ARDL & VAR & Month & ARDL & VAR \\
\hline 1 & 2.7341 & 2.7370 & 7 & 2.7339 & 2.7369 \\
\hline 2 & 2.7341 & 2.7369 & 8 & 2.7339 & 2.7369 \\
\hline 3 & 2.7339 & 2.7369 & 9 & 2.7339 & 2.7369 \\
\hline 4 & 2.7337 & 2.7369 & 10 & 2.7340 & 2.7369 \\
\hline 5 & 2.7338 & 2.7369 & 11 & 2.7340 & 2.7369 \\
\hline 6 & 2.7338 & 2.7369 & 12 & 2.7340 & 2.7369 \\
\hline
\end{tabular}

Table 6. The Comparison of MAPE Value

\begin{tabular}{|c|c|c|c|}
\hline & $\begin{array}{c}\text { MAPE } \\
\text { Data } \\
\text { Training }\end{array}$ & $\begin{array}{c}\text { MAPE } \\
\text { Data } \\
\text { Testing }\end{array}$ & $\begin{array}{c}\text { MAPE } \\
2013- \\
2017\end{array}$ \\
\hline ARDL & $0.5132 \%$ & $0.3356 \%$ & $0.4758 \%$ \\
\hline VAR & $0.4734 \%$ & $0.4338 \%$ & $0.4645 \%$ \\
\hline
\end{tabular}

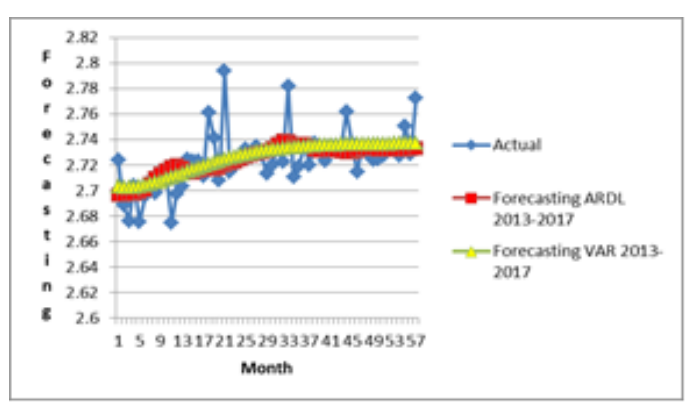

Figure 1 Graphic Forecasting of ARDL and VAR

\section{Conclusion}

Based on the test it is concluded that Autoregressive distributed-Lag model cannot be used because the Koyck assumption does not fulfilled. So to overcome the calculation of Autoregressive Distributed Lag method used Autoregressive distributed-Lag Almon method with the length of lagged is three and polynomial degree is two, For Vector Autoregressive method obtained VAR(1) model. Based on the estimated result it is obtained the MAPE value of data training on the Almon method is about $0.513211 \%$, MAPE value of data testing is $0.335563 \%$, and MAPE value of 2013 to 2017 is $0.475812 \%$. Meanwhile for the VAR method it is obtained the MAPE value of data training on the VAR model is $0.4734 \%$, MAPE value of data testing is $0.4338 \%$ and MAPE value of 2013 to 2017 is $0.464473 \%$. So it can be concluded that Vector Autoregressive (VAR) model is more effective to be used in case study of forecasting of export amount in DIY.

\section{References}

Ansofino, dkk., 2016, Buku Ajar Ekonometrika, Edisi pertama. Yogyakarta: Deepublish. 
Anton H., dan Susilo I., 2000, Aljabar Linear Elementer. Jakarta: Erlangga.

Djuraidah, Anik., Dewi Retno Sari Saputro., dan Aji Hamin Wigena, 1993, Model Vektor Autoregressive (VAR) Untuk Peramalan Curah Hujan di Indramayu. Forum Statistika dan Komputasi, 7-11.

G.S Madala., 1992, Introduction to Econometrics, Edisi 2. New York; Mac Millan PC.

Gujarati, Damodar N., 2003, Basic Econometrics. Singapura: McGraw-Hill,Inc.

Ispriyanti, Dwi., Firdha Rahmatika Pratami., dan Sudarno, 2016, Peramalan Dinamis Produksi Padi di Jawa Tengah Menggunakan Metode Koyck dan Almon. Jurnal Gaussian, 5, 91-97.

Makridakis., 1999, Metode dan Aplikasi Peramalan, Edisi 2. Jakarta: Binarupa Aksara.

Prasetya, Hery., 2009, Manajemen Operasi. Jakarta: Yogyakarta : MedPress.
Rosadi, Dedi., 2012, Ekonometrika Dan Nalisis Runtun Waktu Terapan Dengan Eviews. Yogyakarta: Penerbit Andi.

Setiawan., dan Desi Mustika., 2014, Peramalan Penjualan Sepeda Motor di Jawa Timur dengan Menggunakan Model Dinamis. Jurnal Sains dan Seni Pomits, 3, 224-229.

Sudjana.,1986., Metode Statistika. Tarsito: Bandung.

Sugito., Wilis Ardiana Pradana., dan Rita Rahmawati, 2016, Analisis Pengaruh Kurs Rupiah Terhadap Indeks Harga Saham Gabungan Menggunakan Distributed-lag Model. Jurnal Gaussian, 5, 221227.

Supranto, J., 1995, Pengantar Statistik bidang hukum. Jakarta: Rineka Cipta.

Widarjono, Agus., 2007, Ekonometrika Teori dan Aplikasi untuk Ekonomi dan bisnis, Edisi kedua. Yogyakarta: Fakultas Ekonomi UII. 